\title{
Imaginative Reality In Novel Burung-Burung Manyar By Y.B. Mangunwijaya (Analysis Of New Historicism During The Indonesian Independence Reavolution)
}

\author{
Andri Wicaksono $^{1 *}$, Rohana ${ }^{2}$, Dian Permanasari ${ }^{3}$ \\ Education of Indonesia Language and Literature Program Studies, STKIP PGRI Bandar \\ Lampung, Jalan Khairil Anwar 79, Bandar Lampung, Lampung, Indonesia ${ }^{1,2,3}$ \\ \{ctx.andrie@gmail.com ${ }^{1}$,rohanaana566@gmail.com²,dian_permanasari@gmail.com³
}

\begin{abstract}
Abstrat, Among the various means of representation, such as historical textbooks and mass media that are dominated and voice the interests of the (state) ruler, literary works have attitudes and views that are not always in line with this desire. For this reason, this research describes in detail the historical findings found in literary texts, namely in the novel Burung-burung Manyar by Y.B. Mangunwijaya the creative truth of the nation's struggle during the national revolution. The research method used is qualitative interpretation of events that reflect the historical representation of the struggle of the nation with parallel reading between literary texts. In this study, the data analysis applied is a non-interactive analysis model. Fiction (novels) is an imaginary reality that is structured such writers of various elements forming, such as events, conflict, character, and so on. Therefore the form of narrative sources that contain complete or partial description and tend written, the imaginative fiction of history related to social issues, political, cultural, and religious as well as economic. Imaginative reality or historical value that can be taken from a novel by Y.B Mangunwijaya entitled Burung-burung Manyar is the spirit of nationalism and the spirit of struggle of its characters, about the role in the struggle that fighting does not always have to be in the forefront, cocking weapons, facing real enemies, but also through diplomacy and giving up all thoughts and energy to help the government.
\end{abstract}

Keywords: reality imaginative; Indonesian national revolution; new historicism

\section{Introduction}

The creation of literature in different ways, including historical novels, is a way of expressing ideas in a novel by a writer to maintain part of the novel's substance. Hence, litterateurs treat the context of their artistic works as historical facts and events. In the next step, where literature could be made as a source of history, literature has proven itself to be a science that not only deals with problems of innovation and imagination, but can also become historical records. Therefore, literature can finally break through the confines of its nature as a binding science. From the literary perspective, historical literature is classified as a part of 
literature. In this case, history is not only found in historical writings, particularly those relating to past events, but also in literary works, such as novels.

Based on some modern Indonesian novels' preliminary reading, some novels can be found that depict historical events of the nation's struggle during the war for independence (19451949) which had happened in Indonesia. A literary reader may rediscover the fact or historical portrayal depicted in work of literature by recognizing literary works in relation to the struggle of the country. The New Historicism approach would be used to examine these different issues. Research in which it is using the New Historical approach has been conducted by Paul, which reconciles historical sensitivity in intellectual behaviour by historical contexts with historical scientific non-relativist records [1]. The following research by J.E. Akung explores Nigeria's novel of the new historical aspect that focused on timing consideration in Helon Habila [2].

Kuntowijoyo in Surur mentioned that history varies from literature in terms of process, reliability, overall performance, and conclusion, [3]. Historical novels were born as intellectual and literary answers to the problematic era by reflecting the past. Historical realities appear in novels of history. George Lukacs in Kuntowijoyo mentioned that in the novels history contained several indicators, namely historical authenticity, historical faithfulness, local colour [4]. The opinion of George Lukacs which is used as an indicator in this study is concerned with the value of history in a novel. The indicators of historical value are historical authenticity, historical faithfulness, and local colour.

The objective reality refers to a reality that exists in the real universe that happens such that scientific evidence can prove it. Whether or not something can be exposed in a literary work that is empirically proven is what differs fiction from non-fiction works [5]. Events, places, and characters that are presented in fiction may be imaginary, whereas certain elements are factual in non-fictional works. When we link fact with fiction, reality and fiction in a broad range, it turns out that history and literature are contradictive. As we know that history is reality, factual events that occurred in the past. Meanwhile, the essence of literature is imagination and creativity. Historians and litterateurs, however, interpret this from distinct backgrounds. Reality also acknowledges the importance of the creative elements found in it as the essence of history [6]. Objective reality (historical fact) in history's mind is a realistic statement. Historians express everything in form of expression earnestly and basically. On the other hand, a litterateur describes free interpretation of facts so that his imaginary elements transform the sense of facts.

As a literary genre, author, content creation, language media, and intrinsic elements of fiction are the elements of novel. To examine this, the author presents through explanation or comments, dialogue or monologue, and behaviour [7]. Things that need to be noted down, whereas fiction is included in imaginative literature, with a bigger imagination than biography, history, and memoirs; Fiction can also be used as a historical reflection and historical reference for what happened in the past.

By prioritizing the relationship between text and history, Greenblattt in Budianta breaks down the tendency of formalist textual studies in the new critical a historical tradition, which views literature as an autonomous aesthetic area, independent of aspects that are considered "outside" of the work [8]. Literature, according to the perspective offered by the new historicism, cannot be separated from social, economic, and political praxis because it is included in it. Thus, the separation between inside-outside, extrinsic-intrinsic can no longer be maintained because all texts, both literary and non-literary, are the products of the same era with various power struggles and ideologies, so it is different from the new criticism which only examines literary works. , the new historicism connects literature with non-literary texts. 
In this context, Wiyatmi describes that New Historicism offers a new concept of viewing the relationship between literature and history [9]. Literature in this case is not only seen as a mirror that reflects the culture of society transparently and passively, but literature also contributes to building, articulating and reproducing conventions through verbal action and creative imagination.

The Indonesian novel that became the focus of the study was the work of YB Mangunwijaya, namely Burung-Burung Manyar. Mangunwijaya in his novel wants to urge all Indonesian society, the citizen as well as the nation to reconsider the essence of the 1945 Revolution.

Literary work as a verbal symbol, its object is reality. This reality can be in the form of present social reality or reality in the form of historical events. If history is the reality itself, the journey of this country must be conveyed even though it is through literature learning in schools. This is where the role of Indonesian language and literature learning can be as a means of knowledge, which of course contains the embodiment of historical values. Historical novels can be used as teaching materials to foster a sense of patriotism and nationalism in students. With a spirit of nationalism, future generations will be resilient in facing various problems, especially those related to nation problems.

Previous studies on the War of Independence (Wicaksono, 2018a; 2018b) show that during that revolution, Indonesian literature [10] [11]. The novel, in particular, is involved in various representations regarding the War of Independence. Literature has attitudes and views that are not always in line with these wishes among various means of representation, such as historical textbooks, monuments, museums, and the media, which usually regulate and convey the interests of the ruler (state).

By looking at the above problems, it is necessary to conduct an assessment of the historical value in literature, which is a historical reality. Therefore, the objective of this research is to describe in-depth the reality of the Indonesian national revolution in Burung-burung Manyar by Y.B. Mangunwijaya. Reality imaginative studied in this article is limited to the spirit of nationalism of the characters in novel.

\section{Methods}

With parallel reading between literary texts on events that are the truth of the Indonesian national revolution during the war for independence (1945-1949), the research method used is qualitative interpretive with historical texts explaining the same events. The research object is limited to the imaginative reality in Y.B. Mangunwijaya's Bird-Bird Novel uses a New Historical approach. Content analysis is the technique used in this study [12]. This technique is used to describe the Indonesian national revolution in a novel set during the war for independence (1945-1949). The existence of an intertextual relationship between history and literature or various texts (fictional or factual) reproduced in the same or different time periods) with the perspective of New Historicalism.

The studies used in New Historicism refer to three fundamental assumptions, namely: (1) that any expressive act is closely linked to the functional network of material culture; (2) that literary texts and non-literary texts are inseparable; (3) that there is no discourse at all either fictional or true, giving access to the absolute and unchanged truth or expressing the essence of humanity without any other alternative.

In this study, the data analysis applied is the interactive model which consists of the collection of the data, the reduction of the data, the presentation of the data and drawing 
conclusions or the verification of the data are part of this interactive data analysis [13]. The steps performed in data collection of this study are: a) read repeatedly in whole or in part the novel that is used as a data source; b) collect and study several theories that are relevant to the research objectives; and c) record and analyze all data in the form of important quotes that are relevant to the problem. These three components were carried out interactively, both between components and in the data collection process so that the sequence is a series of interactions. From the presentation of the data, it is possible to draw temporary conclusions followed by verification.

\section{Result and Discussion}

Fiction (novel) is an imaginary reality of a litterateur which is arranged in such a way from various forming elements, such as events, conflicts, characters, and so on. As it is a narrative source that contains complete or partial descriptions and tends to be written, the imaginative side of historical fiction concerns on social, political, cultural, religious and economic issues. The imaginative reality included in this study is limited to cultural, socio-political and economic values.

A novel by YB Mangunwijaya entitled Burung-burung Manyar tells two main characters in the story which is Teto and Atik. The historical background of the Indonesian nation was used as the era of the story by YB Mangunwijaya, starting from the Dutch colonial period, then moving to the Japanese colonial period, and ending during the New Order government. The history of Indonesia during the Japanese colonization until the PJP I of the New Order is represented through a love story of someone who worked to support Indonesian independence, Larasati, and Satadewa alias Teto, an Indonesian who worked in the Dutch army.

This novel is written using the first-person perspective from the perspective of the main character (Setadewa) who is against Indonesian independence. He prefers to be Dutch. The novel Burung-Burung Manyar views the Indonesian revolution in an objective way that tends to be more from the Dutch side by presenting the main protagonist of a mix-blood Indonesian who is anti-Republican.

In Burung-Burung Manyar, YB Mangunwijaya showed a lot of experience as well as deep knowledge of humans. His tone is humorous but sharp. It causes the reader to analyze himself and tease himself. It contains brand-new lexicon and high levels of compound vocabulary to convey as much meaning as possible, funny and full of satire. The language used can bring the reader into the realm of the characters' mind. It is said that the typical language of "mangunwijayaan" and its contents is harsh and strict, but also romantic, gentle, and affectionate.

Mangunwijaya clearly describes the relationship between Atik and Janakatamsi as longlasting until "death do them part". Most readers will probably have more sympathy towards Teto because it is more humane, there are good and bad sides.

YB Mangunwijaya in this novel presents a very complex problem. His work involves various characters with different characters. The characters featured in the work come from various social classes. Inside there are characters of aristocratic descent, educated figures, and there are figures in the lower class (domestic servants) that are not educated.

In this novel, the author also tries to show his deep thought and experience of humans. In this novel, YB Mangunwijaya views the Indonesian revolution from an objective point of view and even tends to see it from the Dutch point of view by putting up an anti-republican protagonist. The author tries to open the layer of history with a different perspective in which 
each event revealed presents self-analysis and criticism and allusions about falsity and human identity.

The following is an analysis rubric of research work on the imaginative reality aspects of Burung-Burung Manyar novel by YB Mangunwijaya in terms of the intrinsic elements of literary works (novels) and historical value in the novel. The fictional structures used and selected in this study include the theme, plot, setting (time and location), and characters. Meanwhile, the historical values used as study material are cultural, socio-political and economic values.

Table 1. Summary Analysis of Reality Imaginative

\begin{tabular}{ccccccc}
\hline \multicolumn{3}{c}{ Novel Intrinsic Elements } & \multicolumn{3}{c}{ Historical Value } \\
\hline Theme & Plot & Setting & Characters & Cultural & $\begin{array}{c}\text { Socio- } \\
\text { political }\end{array}$ & Economy \\
20 & 19 & 6 & 16 & 16 & 27 & 6 \\
\hline
\end{tabular}

From the table above, it is known that the imaginative reality of novel Burung-burung Manyar by Mangunwijaya YB work is reviewed from the theme elements consisting of 20 data findings, then from the flow elements found 19 data, on the background elements (place and time) there are 6 data, then the character elements there are 16 data. Judging from the historical value elements that cover it, the imaginative reality of the war of independence identified from novel Burung-Burung Manyar by YB Mangunwijaya found 16 data on cultural values, there were 27 data of socio-political values and the government found, then economic value there were 6 data.

From historical values, the main problem is the sense of nationalism and nationalism that the characters have in the novel. Larasati and the Antana family are examples of characters that defend and fight for Indonesian independence. Meanwhile, from the opposite side, the Dutch defenders were Setadewa and his father, Captain Brajabasuki.

In the physical revolution, Teto sided with the Dutch by becoming a KNIL officer. He thought whoever helped Japan or at least agreed with Japan, they were an enemy that had to be fought. He thought that Japan is considered to be responsible for destroying her mother's life because of Japan's inhuman treatment of her mother in making her a concubine.

Memang kita dari dunia yang berlainan, Atik...ya beginilah jadi Atik berkerja sebagai sekretaris pada pemerintah pemberontak itu? Mulai sekarang kita akan membuktikan, siapa yang benar. Dengan realita kejam! Kau juga Tik, semoga kau dan ibumu semoga kau dan ibumu selalu terlindung oleh Tuhan, kalau itu ada, Tik." (Mangunwijaya, 2010:71).

Regarding the nationalism of the characters in Burung-Burung Manyar, nationalism can be considered as a historical phenomenon and emerges as an answer to certain historical, political, economic, and social conditions [14].

If we look at it from the point of view of the situation and condition of Indonesia's history, nationalism is the most important result as a consequence of the influence of Western power in its colonized countries. Nationalism as a historical phenomenon has developed in response to the political economy, and social conditions in particular, which were caused by the colonial situation. Responding to the nationalism that the government promotes as a movement that put the nation's and country's business above personal business, YB Mangunwijaya has a different opinion. He saw that officials, such as king, regents, and even the head of the village, often enslaved the people themselves and the cunning tricks of the 
colonizers, among them, depleted Indonesia's natural wealth through officials who were made under him.

Aku dulu masuk NICA. Mau apa! Sekarang aku tahu, itu kliru. Tetapi apa manusia tidak boleh keliru? Lagi, pada saat itu, aku yakin bahwa apa yang dikehendaki kaum nasionalis keliru. Orang-orang Indonesia belum matang untuk merdeka. (Mangunwijaya, 2010:69)

Kemenangan nasional bagi Atik dibayangi oleh sayap elang gelap bila mengingat nasib Teto sekarang. Apakah dia akan dapat menerima kekalahannya? Bagi Atik dan barangkali untuk setiap wanita yang mencinta, soalnya bukan kalah atau menang, sebab permainan sondakh mandakh, cinta tidak mengenal itu. (Mangunwijaya, 2010: 208)

Indonesian nationalism has a typical characteristic that is different from nationalism anywhere in the world. The pure Indonesian nationalism is a form of resistance towards colonialism [15]. Therefore, nationalism has always been understood as an ideology which declares that individual loyalty and devotion must be submitted to the Indonesian nation to seize independence from the colonialists and at the same time defend it.

Mangunwijaya's point of view regarding nationalism through Teto is different. Nationalism in gaining independence, through Teto's attitude, is not based on teto's participation in one party which is said to be the truth, but it is based on the courage to vote instead [16]. Even though he finally realized that his choice 'maybe' wrong and he has to give up his love for Larasati, Teto stands still as an independent person, as a person who overcame the chains of idealism about 'national'.

Darmawati calls this national identity, which is the identity inherent in a nation and signifies it as a nation [17]. National identity is a feature that distinguishes it from other nations so that each nation in this world has its own identity in accordance with the uniqueness, nature, characteristics and character of that nation. In the context of literature, literary works are full of various guidelines for life, either in the form of instructions, teachings or prohibitions or restrictions.

The author raises the conflict about national behaviour among the characters. As described above, Atik and Teto often argue about attitudes towards nationalism and patriotism of the country. This unfavourable situation brings a negative effect on these two characters. Teto and Atik repeatedly engage in a tight conversation and seem to want to be wanting to part.

"Pasukanku menang, Kapitein Setajaya. Tetapi kehilangan Larasati. Barangkali...

barangkali toh aku salah pilih," (Mangunwijaya, 2010:127).

The above quote shows Teto's feelings and thoughts towards Atik and also his interest in always accompanying Atik has faded and there is no more chemistry between them. According to Arifin (2015), the difference in the sense of nationalism between the couple has a negative influence on their personalities [18]. The negative effect is mainly on Teto. Teto will have a high probability that he will lose Atik because they are working on different sides and those sides have opposite wishes.

KNIL can claim that Teto is a traitor soldier to the Kingdom of the Netherlands because he keeps contacting with Atik who is originally Indonesian. He risks his position as a KNIL soldier if he keeps in touch with Atik. For Atik, being in a bad term with Teto affects her. She will lose the opportunity to meet Teto because his job is quite strict and remains focused on the condition of Indonesia which is currently struggling. Besides, Atik is in danger because of her job as secretary to the Prime Minister Syahrir, who is being targeted by the Dutch to be killed because he was considered as a threat to the Netherlands. Atik might also be one of the targets for the Netherlands.

Teto then realized and recognized himself that he is only a KNIL troop, a soldier hired by the Dutch, and he realized that all this time he only hates from certain Japanese and 
Indonesian individuals, not Japan and Indonesia as the whole nation.

This is in accordance with the written Tengsoe Tjahjono that Burung-burung Manyar successfully entered into the deepest aspects of the dimension of nationalism that includes psychological dimension, the dimension of sociological and historical dimensions, namely upheaval and soul consciousness figures [19]. All that contain in the literary works such as the events, conflicts, and ideas is not an autonomous entity, because literature was mainly the representation of human being existence. So that the fact of nationalism in Burung-burung Manyar nationalism is a fact that did occur in the throes of the nation in the search for, find, and make sense of nationalism. Burung-burung Manyar are an effort of Y.B. Mangunwijaya discussed nationalism in a narrative and metaphorical manner. The use of autobiographical techniques, the use of multiple points of view, and the narrative in plot, characters and themes, succeeded in articulating the Indonesian nationalism experienced by the figures. Finally, it has a significant relationship between Y.B. Mangunwijaya with the thought of nationalism in Burung-burung Manyar. This proves that reading Burung-burung Manyar actually reads the thought of nationalism Y.B. Mangunwijaya which is constructed into literature.

Through this novel, Mangunwijaya would urge the entire community, the people and the Indonesian people to reflect on the essence of the Revolution of 1945. Teto and Larasati, characters who fail and characters who succeed. Characters who are enemies and figures who side with the conscience, Kauravas and Pendawa, about Balarama and Larasati, Arjuna, and so on.

\section{Conclusion}

From the research results, the conclusions that can be drawn from the imaginative reality novel Burung-Burung Manyar by YB Mangunwijaya are as follows. The imaginative reality or historical value that can be taken from the novel Burung-Burung Manyar by YB Mangunwijaya is the sense of nationalism and the sense of the struggle of the characters, about the role of struggle that struggling does not always have to be in the frontline, prepare your weapons, face real enemies, but also through diplomacy and giving all thoughts and energy to help the government. As what Larasati does who works at the Prime Minister Syahrir's office. She was willing to sacrifice his love and feelings to defend his nation from colonialism.

\section{Acknowledgement}

Thanks are conveyed to LLDIKTI II Palembang for funding this research activity. The researchers also thank the Chairperson of STKIP PGRI Bandar Lampung who has helped, supported, provided data and information for this research.

\section{References}

[1] Herman Paul, (Department of History, Leiden University the Netherlands), "Weak Historicism: On Hierarchies of Intellectual Virtues and Goods", Journal of the Philosophy of History, Volume 6, Issue 3, 2012, pp. $369-388$. 
[2] Jonas Egbudu Akung, "New Historicist Dimensions in Helon Habila's Measuring Time", International Journal of Applied Linguistics and English Literature, Vol 1, No. 4, 2012.

[3] Misbahus Surur, "Mengais Realitas dalam Novel Sejarah", Artikel, tersedia (online) https://www.academia.edu/2015, 2015, diunduh pada 18 Juli 2018.

[4] Kuntowijoyo. Pengantar Ilmu Sejarah. Yogyakarta: Bentang Budaya, 2005.

[5] Burhan Nurgiyantoro, Teori Pengkajian Fiksi, Yogyakarta: Gajah Mada University Press, pp. 2, 2009

[6] Nyoman Kutha Ratna, Antropologi Sastra. Peranan Unsur-unsur Kebudayaan dalam Proses Kreatif. Yogyakarta: Pustaka Pelajar, . 2011.

[7] M. Atar Semi, Metode Penellitian Sastra. Bandung: Angkasa, 2012., pp. 66

[8] Melani Budianta, "Budaya, Sejarah, dan Pasar: New Historicism dalam Perkembangan Kritik Sastra,” yang dimuat dalam Jurnal Susastra Volume 2, No. 3, tahun 2006

[9] Wiyatmi. "Representasi Sejarah Sosial Politik Indonesia dalam Novel-novel Karya Ayu Utami”. Laporan Penelitian. FBS-UNY Yogyakarta, 2012, pp. 8

[10] A. Wicaksono; Emzir; and Z. Rafli. History of Indonesia's War Independence in Novel Larasati by Pramoedya Ananta Toer: New Historicism Approach. DOI: $10.5220 / 0008993400320040$. In Proceedings of the International Conference on Education, Language and Society (ICELS 2019), pages 32-40.

[11] Andri Wicaksono. Makna perjuangan dalam novel Indonesia berlatar perang kemerdekaan (Tinjauan New Historicism Greenblatt). Jurnal Pendidikan Bahasa dan Sastra, 2018, 18(2), doi: 10.17509/bs_jpbsp.v18i2.15509

[12] P. Mayring, "Qualitative Content Analysis". Dalam Forum Qualitative Sozialforschung, Volume 1, No.2, Juni 2000, p.14

[13] Mattew B. Mills, dan A. Michael. Huberman, Analisis Data Kualitatif. Jakarta:Universitas Indonesia, 2007., pp. 19-20.

[14] Sartono Kartodirjo, Sejarah Pergerakan Nasional, dari Kolonialisme sampai Nasionalisme. Jakarta : PT Gramedia Pustaka Utama, 1999.

[15] Suhartono. Sejarah Pergerakan Nasional dari Budi Utomo Sampai Proklamasi 1908-1945. Yogyakarta : Pustaka Pelajar, 1994.

[16] Mulyono. Nasionalisme dan Refleksi Sejarah Indonesia Novel BurungBurung Manyar Karya Y.B. Mangunwijaya. Tesis. Program Studi Pendidikan Bahasa Indonesia, Program Pascasarjana, Universitas Negeri Semarang, 2008.

[17] Besse Darmawati. "Menggugah Identitas Kebangsaan Melalui Puisi", Jentera, Volume 6, Nomor 1, Juni 2017, p. 42-63.

[18] Amirah Wulansari Arifin, Problem Kejiwaan Setadewa terhadap Nasionalisme dalam Novel Burung-Burung Manyar Karya Y.B. Mangunwijaya. SIROK BASTRA, Vol. 3 No. 2, Desember 2015: 171-178

[19] Tengsoe Tjahjono. Nationalism in Y.B. Mangunwijaya's Burung-burung Manyar. Dissertation. Indonesian Language Education Study Program Graduate School Malang State University, 2012. 